\title{
COMO EU VEJO O OCIDENTE? ${ }^{1}$
}

Şahin Alpay²

Estou habituado a fundamentalistas islâmicos ou leninistas me acusarem, aqui e ali, de ser um bajulador, lacaio, adulador, etc., de imperialistas ocidentais devido ao meu comentário em favor da adesão da Turquia à União Europeia e de sua filiação à Aliança Ocidental.

É por isso que fui recentemente um pouco surpreendido quando um amigo meu, com quem eu tenho muitos pontos de vista em comum, disse-me que sentiu certas tendências anti-ocidentais em mim com base em meus comentários sobre o massacre ao Charlie Hebdo em Paris no mês passado. Talvez seja uma boa idéia que eu esclareça a minha posição sobre o Ocidente.

Eu acredito em um mundo onde a democracia, o secularismo (no sentido da liberdade de religião e de consciência para todos), os Direitos Humanos e o Estado de direito prevaleçam; onde ninguém seja discriminado com base em gênero, raça, origem étnica, crença religiosa, deficiência ou orientação sexual; e onde os conflitos sejam resolvidos não pela violência ou pela guerra, mas através do diálogo pacífico e da negociação.

Estou convencido de que tais princípios e instituições definem a civilização contemporânea, que se baseia nas experiências comuns da humanidade ao longo dos tempos. Eu defendo que o conflito básico no mundo de hoje não é entre civilizações baseadas na religião - entre o Islã e o Ocidente, em particular, como o falecido Samuel B.

\footnotetext{
1 Tradução do original "How do I view the West?", texto de Şahin Alpay publicado no periódico turco Today's Zaman em 9 de Fevereiro de 2015. Tradução livre por Natalia Nahas Calfat. Disponível em: [http://www.todayszaman.com/columnist/sahin-alpay/how-do-i-view-the-west_372066.html]. Último acesso em 14 de Fevereiro de 2015. Tradução ao português a ser publicada na Revista Malala autorizada pelo autor em 9 de Fevereiro de 2015.

2 Şahin Alpay nasceu em Istanbul em 1944, atualmente é professor da Universidade turca Bahcesehir em Ciência Política e Relações Internacionaise e colunista do Jornal Zaman (Zaman Gazetesi) e do Today Zaman.
} 
Huntington argumentou -, mas sim entre aqueles que defendem a civilização contemporânea e aqueles que a rejeitam em todos os lugares.

Pode-se dizer que os países da América do Norte e da Europa Ocidental - após amargas experiências ao longo dos séculos e após terem infligido muito sofrimento sobre o resto da humanidade - têm, em grande medida, sido capazes de estabelecer os princípios e instituições da civilização contemporânea em casa, na esteira da Segunda Guerra Mundial. É por isso que eu aprecio as conquistas do Ocidente, as julgo como mais bem sucedidas que as do Resto, e apoio que a Turquia se torne parte do Ocidente nesse sentido.

Isso, no entanto, não significa absolutamente que eu aprove o Ocidente em todos os aspectos. Oponho-me tanto às intervenções militares ocidentais em outros países, a fim de promover seus interesses, como à sua abstenção de intervir quando necessário por razões humanitárias. Para dar exemplos do período após o fim da Guerra Fria, eu me opus fortemente à guerra no Iraque da ex-administração do presidente dos EUA, George W. Bush, que resultou em uma tragédia, cujas terríveis consequências o mundo ainda está sofrendo. Eu também sou altamente crítico à política da administração do presidente norte-americano Barack Obama de negar apoio substancial para o povo da Síria em sua revolta contra a ditadura do presidente sírio, Bashar al-Assad, que em determinadas maneiras contribuiu para as circunstâncias através das quais os povos da região são confrontados com o flagelo que é o Estado Islâmico do Iraque e do Levante (ISIL).

Eu desprezo o Orientalismo no Ocidente, que olha para baixo e despreza os povos do Resto em geral, e os muçulmanos em particular. Minha admiração pelos princípios e instituições da integração europeia hoje não quer dizer, em qualquer sentido, que eu seja alheio ao fato de que o colonialismo, o nacionalismo racista, agressivo, o fundamentalismo secular e o totalitarismo são também produtos europeus. Estou altamente alarmado pelas semelhanças entre o antissemitismo de ontem e a islamofobia de hoje na Europa. 0 discurso de ódio dirigido contra judeus parece ser proibido em princípio, mas livre quando contra os muçulmanos.

Eu acredito que a mentalidade do "Clube Cristão" desempenhou um certo papel tanto na adesão da Turquia à União Europeia ter chegado a um impasse, quanto em cipriotas gregos terem ingressado no clube enquanto os cipriotas turcos foram deixados de fora. Estou convencido de que o problema israelo-palestino só pode ter uma solução 
de dois Estados. Não tenho dúvidas de que o apoio incondicional emprestado por países ocidentais, com os Estados Unidos na liderança, às políticas intransigentes de Israel, é a principal razão para a ascensão do islamismo radical violento.

A atrocidade cometida contra os cartunistas do Charlie Hebdo é desprezível, e assim como todos os terrorismos, o terrorismo islâmico deve ser condenado e reprimido. Mas a ventilação da islamofobia por fundamentalistas seculares é inaceitável, notadamente sob as atuais condições da crescente onda de xenofobia e de racismo na Europa.

Desnecessário dizer que minhas posições são em grande parte determinadas pelo fato de que eu sou um turco que toma uma posição em favor da civilização contemporânea como eu a entendo. 